\title{
" تأثير برنامج تدريبي باستخدام قناع التدريب على بعض القدرات البدنية والمستوى الرقمى لاعبى ، . . م صدر "
}

\section{الباحث/لحيي أبو السعود سيد محمود}

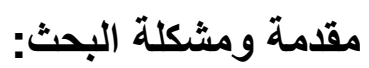
يتميز العصر الحديث بتطور فروع العلم فى كافة مجالاته بشكل يفوق التصور عن مثيلاته
\end{abstract}

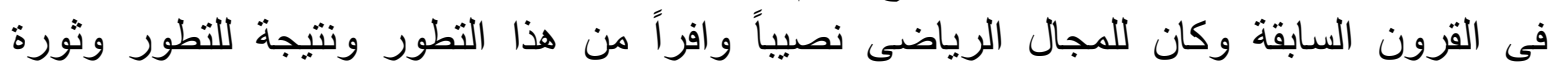

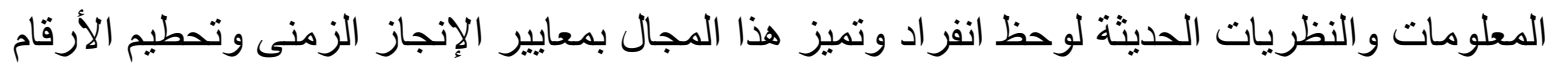

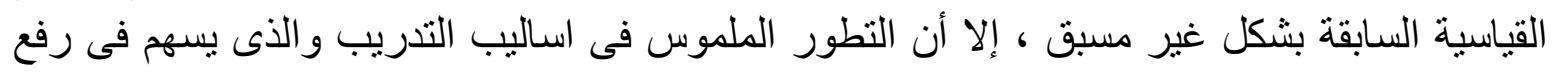

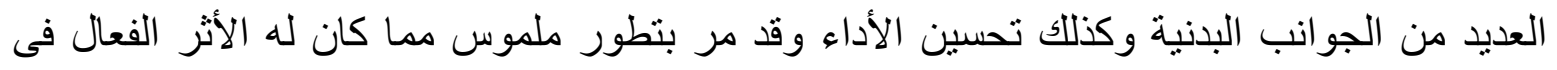

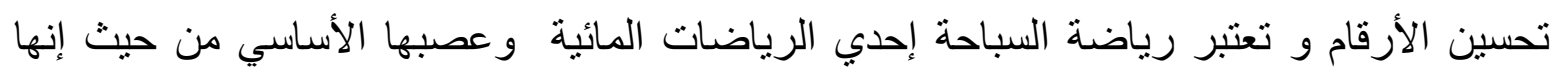

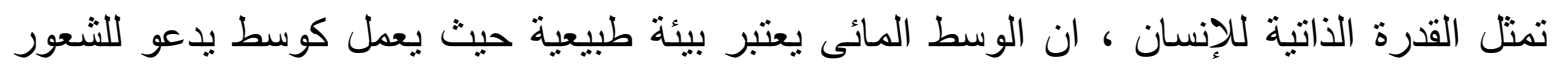

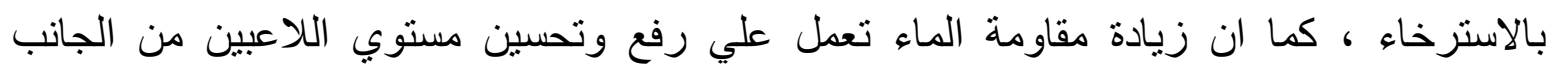

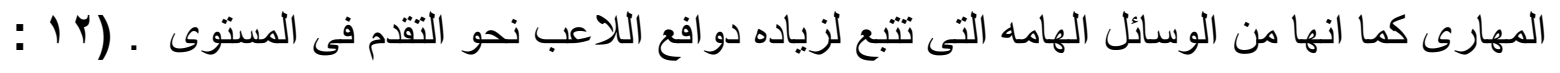

$$
\text { (Or: ) (ro }
$$

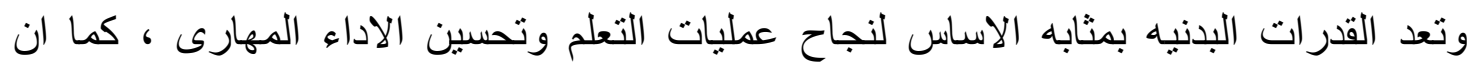

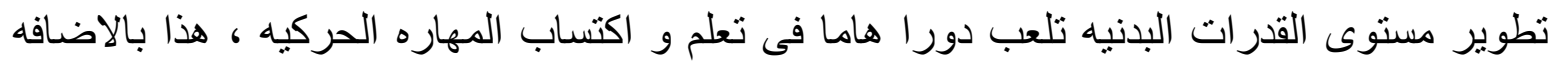

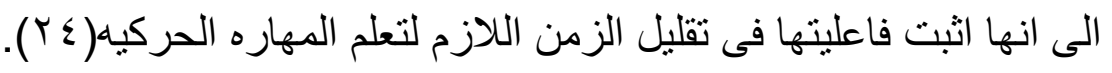

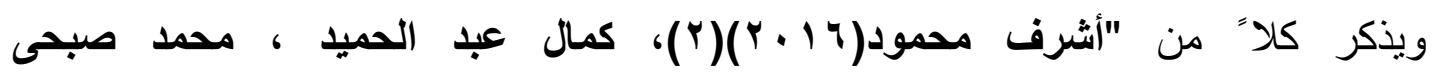

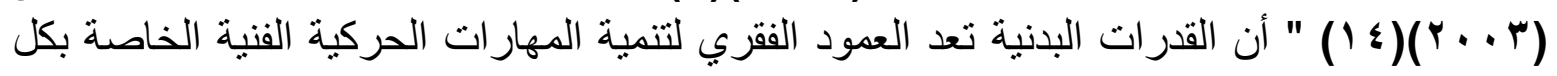

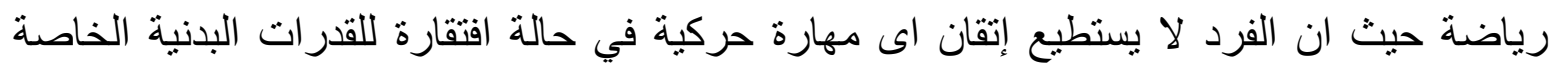

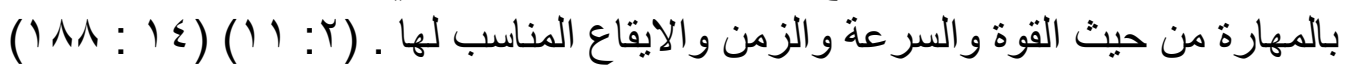

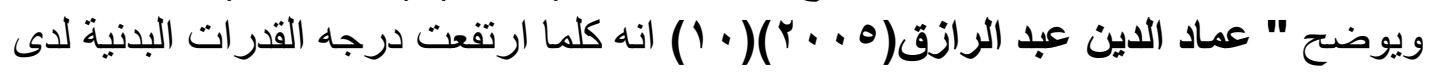

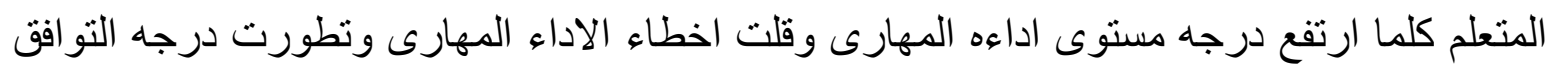

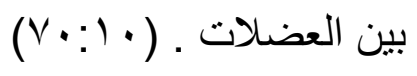

وتعتبر حركات السباحة بمختلف أنو اعها ضمن تللك المهار ات أو الحركات التي يتطلب أدائها

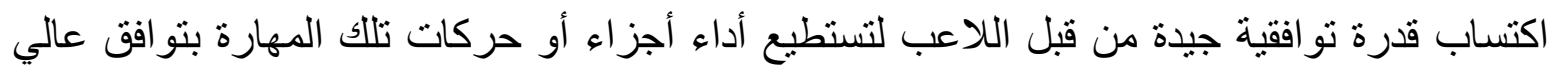

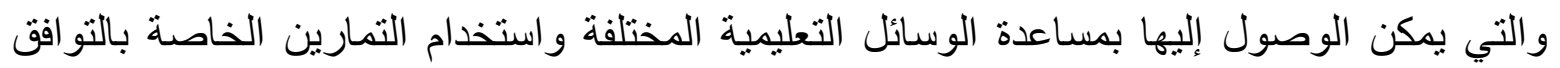

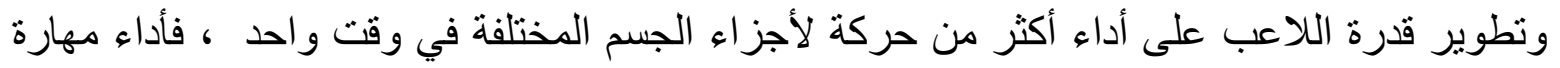

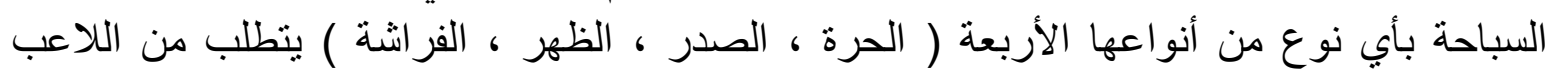


تحريك كل من الر أس و الذر اعين و الرجلين معا" في وقت واحد وباتجاهات أو مسار ات حركية مختلفة

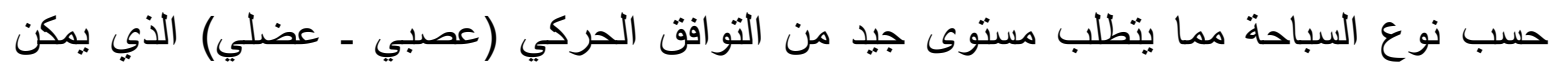

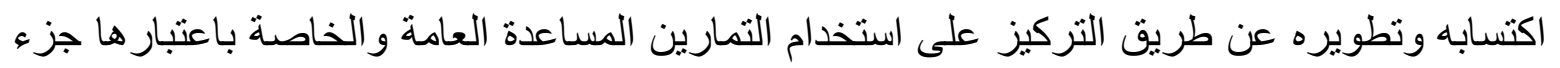

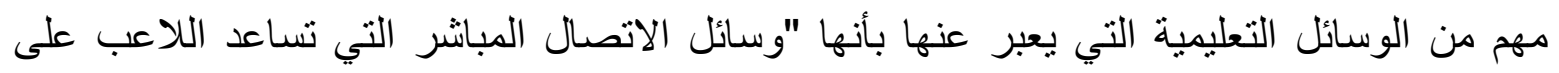

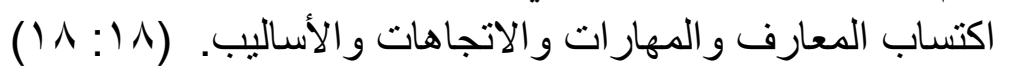

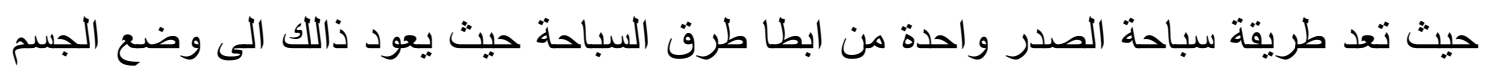

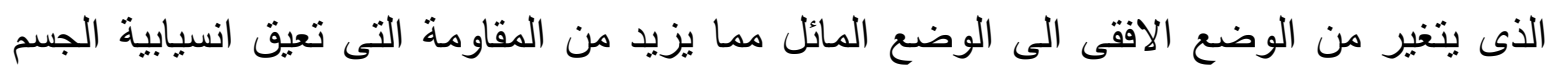

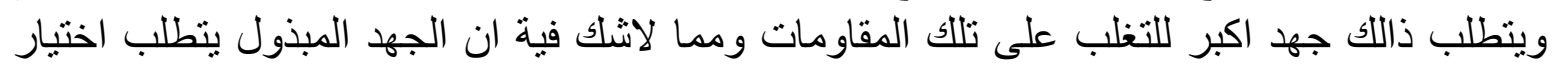

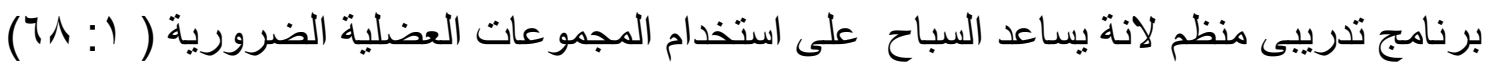

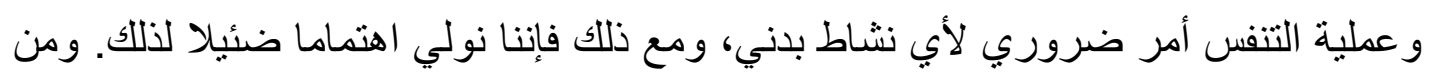

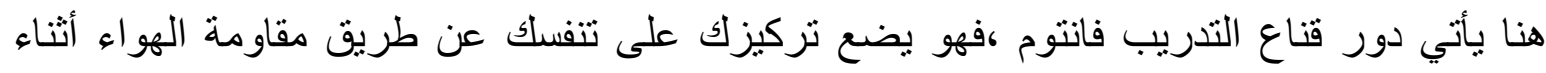

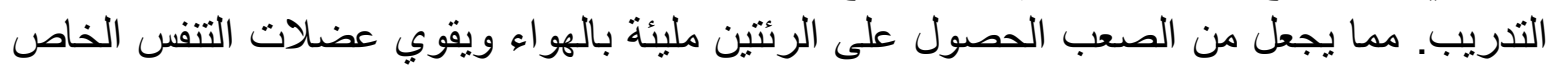

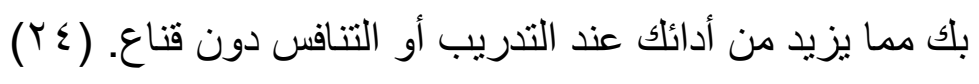

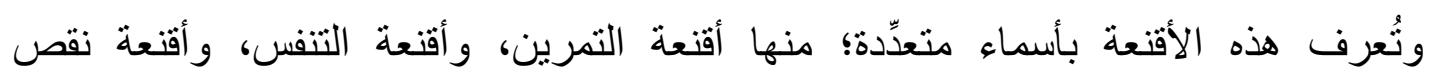

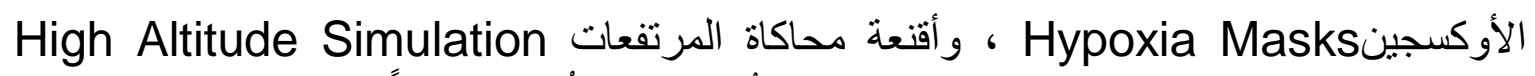

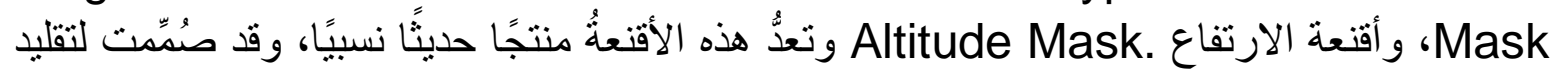

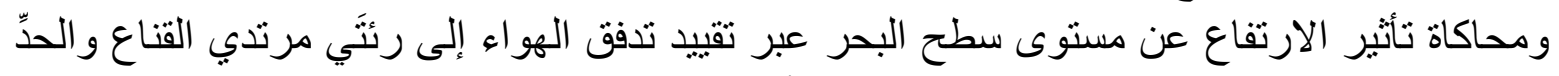

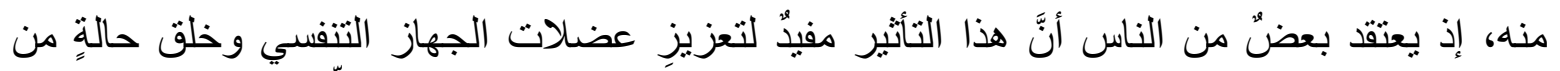

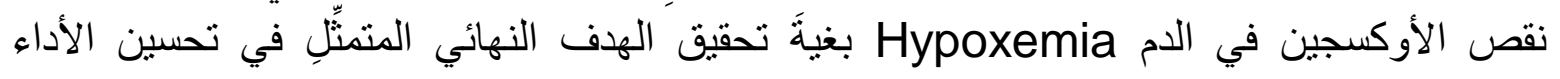

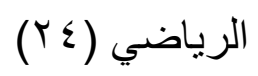

ومن خلال الاطلاع والمسح المرجعى للمراجع والابحاث العلمية فى مجال السباحة

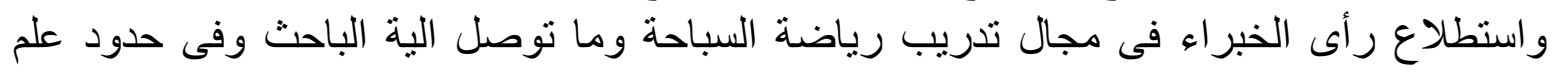

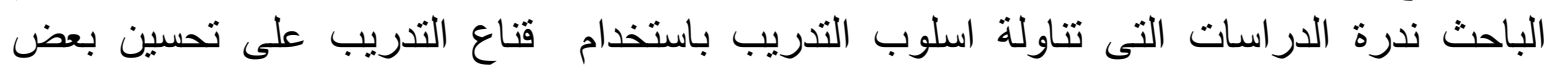

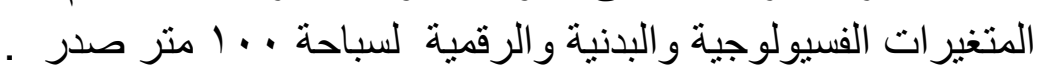

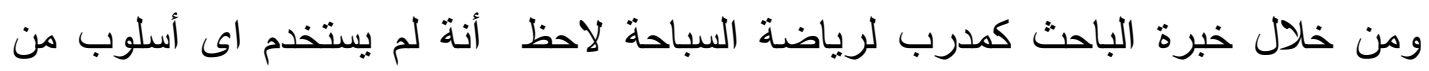

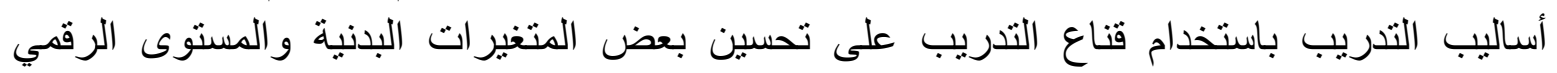

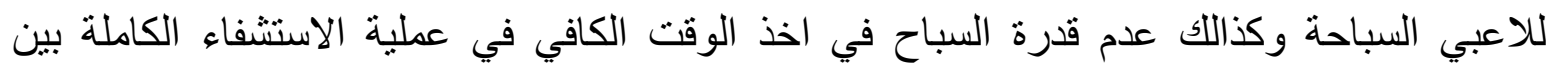

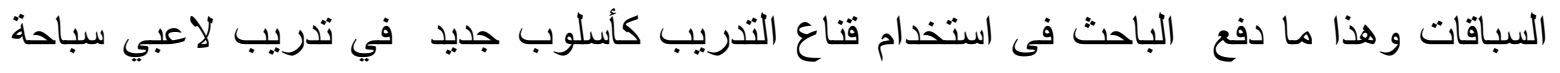

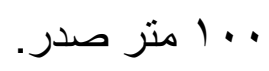




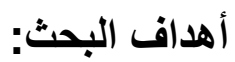

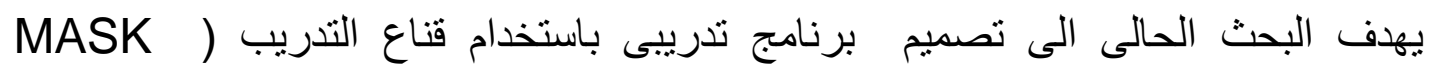

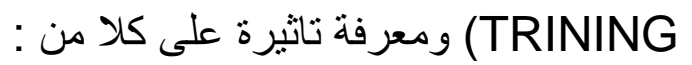

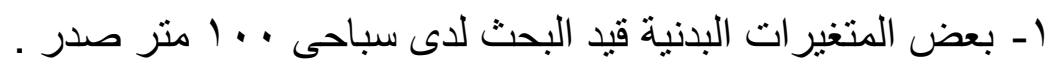

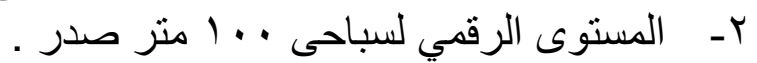

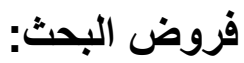

- توجد فروض دالة إحصائيا بين متوسطات القياسين البعديين للمتغيرات البدنية قبد البحث

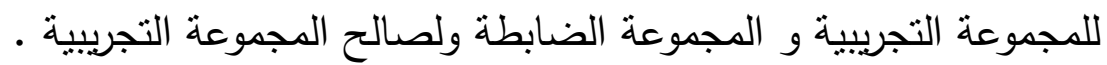
- توجد فروض دالة إحصائيا بين متوسطات القياسين البعديين للمستوى الرقمي للمجموعة التجريبية و المجموعة الضابطة ولصالح المجموعة التجريبية.

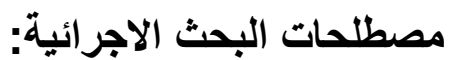

سر عه وكفاءه تعلم المهار ات الاساسيه ثم استخدامها الاستخدام الامثل باقل قدر من الجهد وبالسر عها

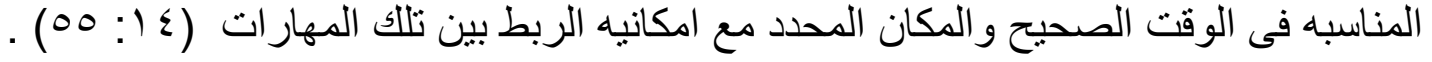

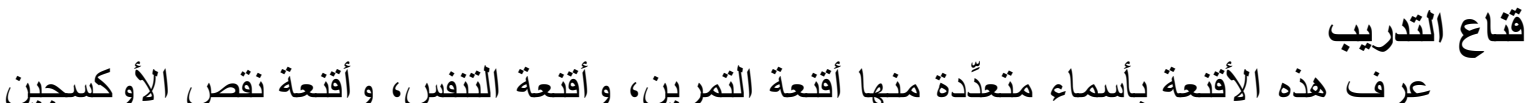
Hypoxia Masks

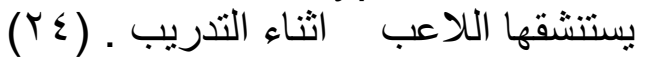
إجراءات البحث: - اء

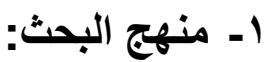

استخدم الباحث المنهج التجريبي ذات التصميم التجريبي لهجموعتين احداهما تجريبية والاخرى ضابطة وذلك لملائمة لطبيعة البحث

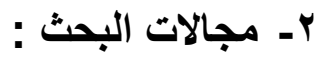

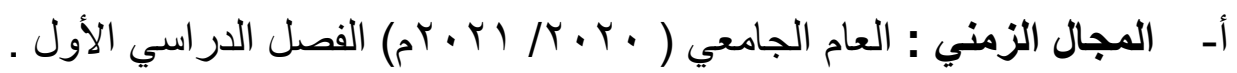

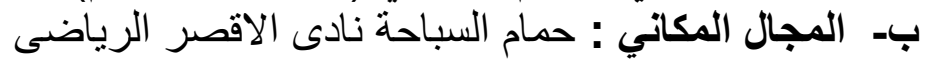
تـ المجال البشري : فريق نادى الاقصر الرياضى الاضئ الريات 
تحد مجتمع البحث: من لاعبين نادى الاقصر الرياضى لسباحة . . ام صدر.

تم اختيار لاعبين لاعبين نادى الاقصر الرياضى لسباحة ... ام صدر بالطريقة العددية

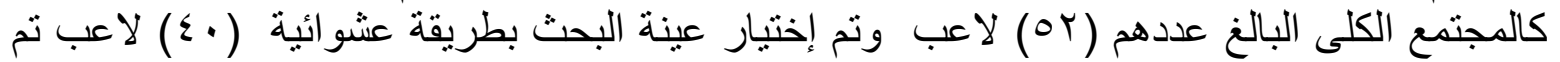

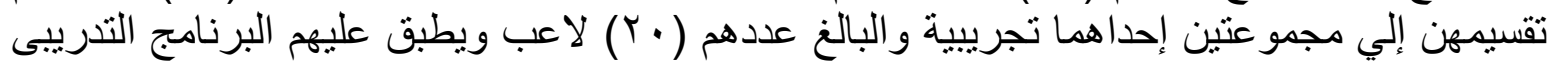

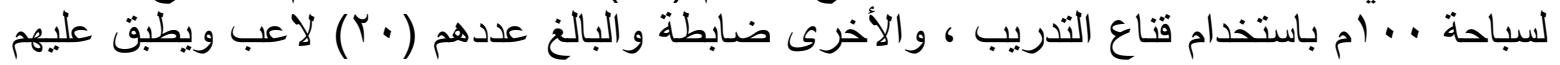

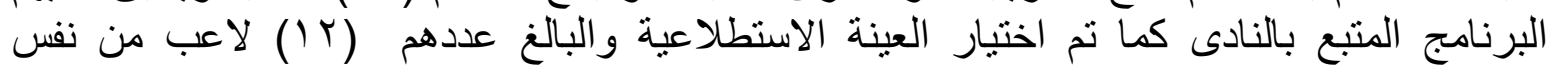

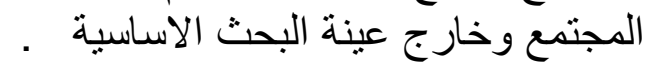

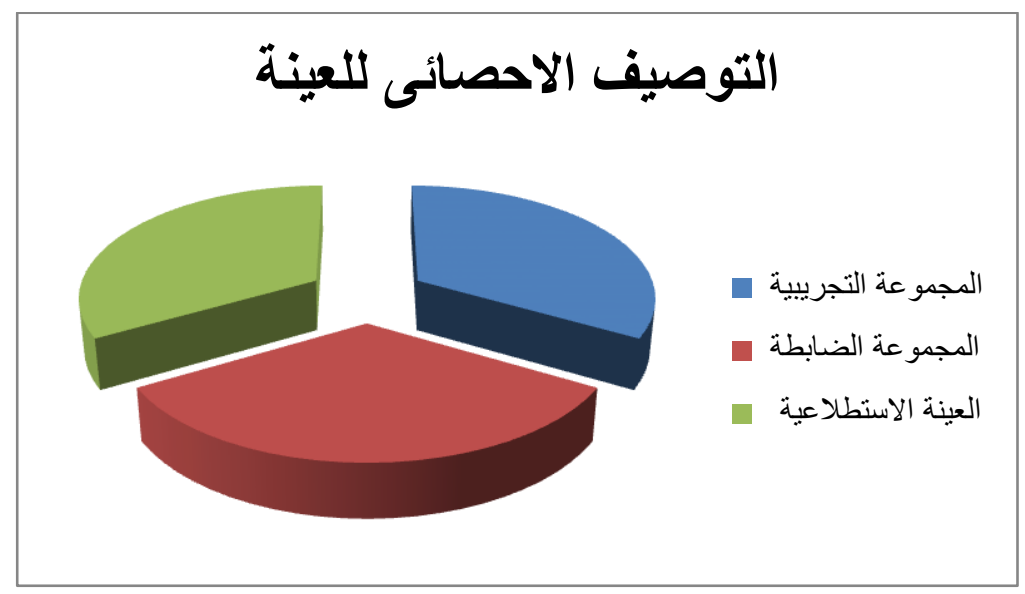

شكل( ( ) ) التوصيف الاحصائي لعينة البحث

- تجانس مجموعتي البحث (التجريبية ـ الضابطة)

تم حساب التجانس بين أفر اد عينة البحث الكلية (التجريبية- الضابطة) في (القياسات الأنثربومترية

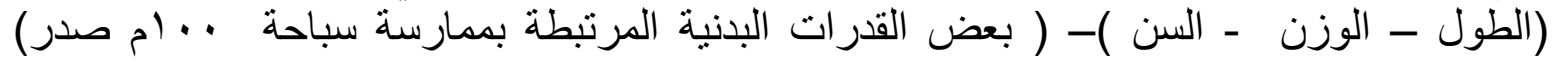

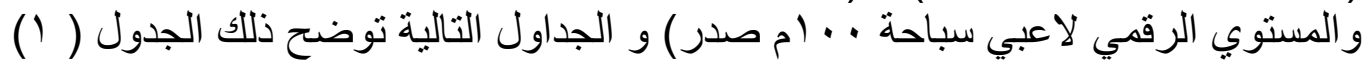

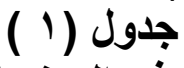

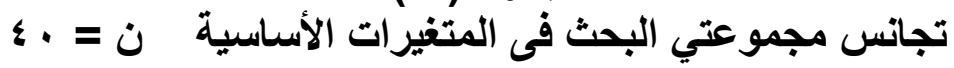

\begin{tabular}{|c|c|c|c|c|c|c|c|}
\hline التفلطح & الإلتواء & المعيارى الإنحراف & الوسيط & الحسابى & والقياس & الدلالات الإ & p \\
\hline..$O Y$ - & $\cdot . \Lambda \varepsilon$ &. .21 & $9 . \wedge$. & 9.01 & سنه & السن & 1 \\
\hline$\cdot .9$ & $\cdot . \mu r$ & $\varepsilon . \wedge \wedge$ & $1 \% \varepsilon$ & $1+\varepsilon .1$. & سم & الطول & $r$ \\
\hline$\because \diamond \Lambda_{-}$ &. .11 & $7 . \wedge \wedge$ & $r . .0$. & $r \cdot . r \wedge$ & سم & الوزن & $r$ \\
\hline
\end{tabular}




\begin{tabular}{|c|c|c|c|c|c|c|c|}
\hline..$Y$. &.$V V$ &. $.7 r$ & $\varepsilon . \wedge 1$ & $\varepsilon .91$ & $\dot{H}$ & الدو ائر المرقمه & $\varepsilon$ \\
\hline$\cdot . \varepsilon r_{-}$ & $\because Y \leqslant-$ & 1.9 & 0 & $\varepsilon . \wedge \Lambda$ & سم & ثني الجذع من الوقوف & 0 \\
\hline. .09 & $\because .0-$ &..$\wedge V$ & 9.57 & $9.0 Y$ & $\dot{H}$ & الجري المكوكي & 7 \\
\hline. .11 &..$V V$ &. .11 & $1 . Y$ & $1 . Y V$ & b & الوثب العريض & $V$ \\
\hline$\because V \theta_{-}$ & $\because Y \leq=$ &. .81 & 1.00 & $1 \cdot .7 r$ & $\dot{H}$ & الثبات في وضع الطفو & $\Lambda$ \\
\hline$\cdot .7 Y=$ & $\because \cdot \Lambda_{-}$ &..$\Lambda \Lambda$ & $V 7.0$. & $V 7.80$ & ث & سباحة ، . ام صدر & 9 \\
\hline
\end{tabular}

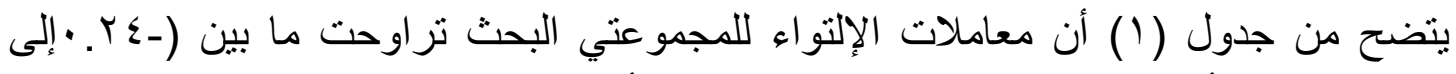

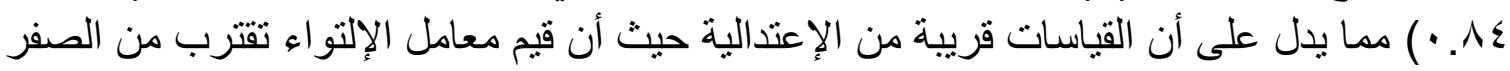

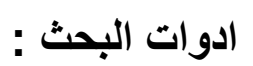

اولا : استمارة القدرات البدنية البذنية المرتبطة بممارسة سباحة . . ام صدر والاختبارات التى

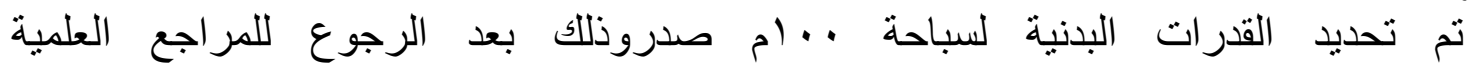

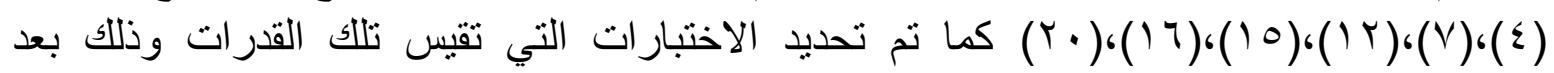

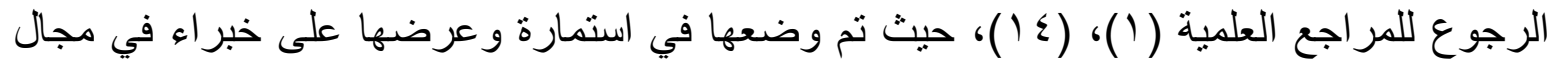

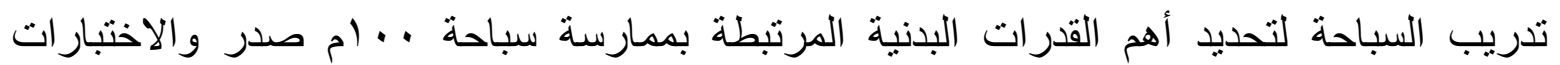

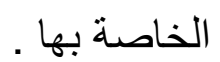

$$
\text { جدول (r) }
$$

\begin{tabular}{|c|c|c|}
\hline 1. = ن & \multicolumn{2}{|c|}{ استطلاع راى الخبر اء لتحديد القدرات البدنية البدنية } \\
\hline النسبة المئوية & 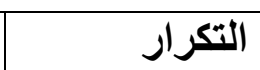 & القدرات البدنية البدنية \\
\hline$\% 1 \ldots$ & $1 \cdot$ & 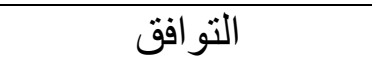 \\
\hline$\% 9$. & 9 & 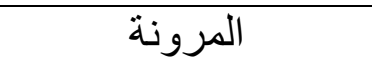 \\
\hline$\% 1 \ldots$ & 1. & الرشاقة \\
\hline$\% 1 \ldots$ & 1. & القوة المميزة بالسر عة \\
\hline$\% 9$. & 9 & التوازن \\
\hline
\end{tabular}

ارتض الباحث نسبة إنفاق الخبراء 9 \% حيث اتفق الخبراء علي القدرات البنية (التوافق-

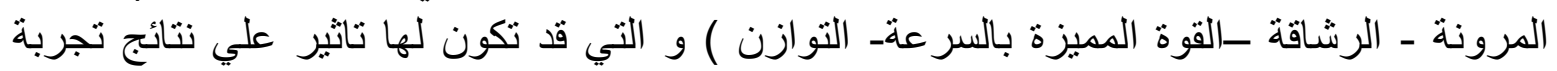




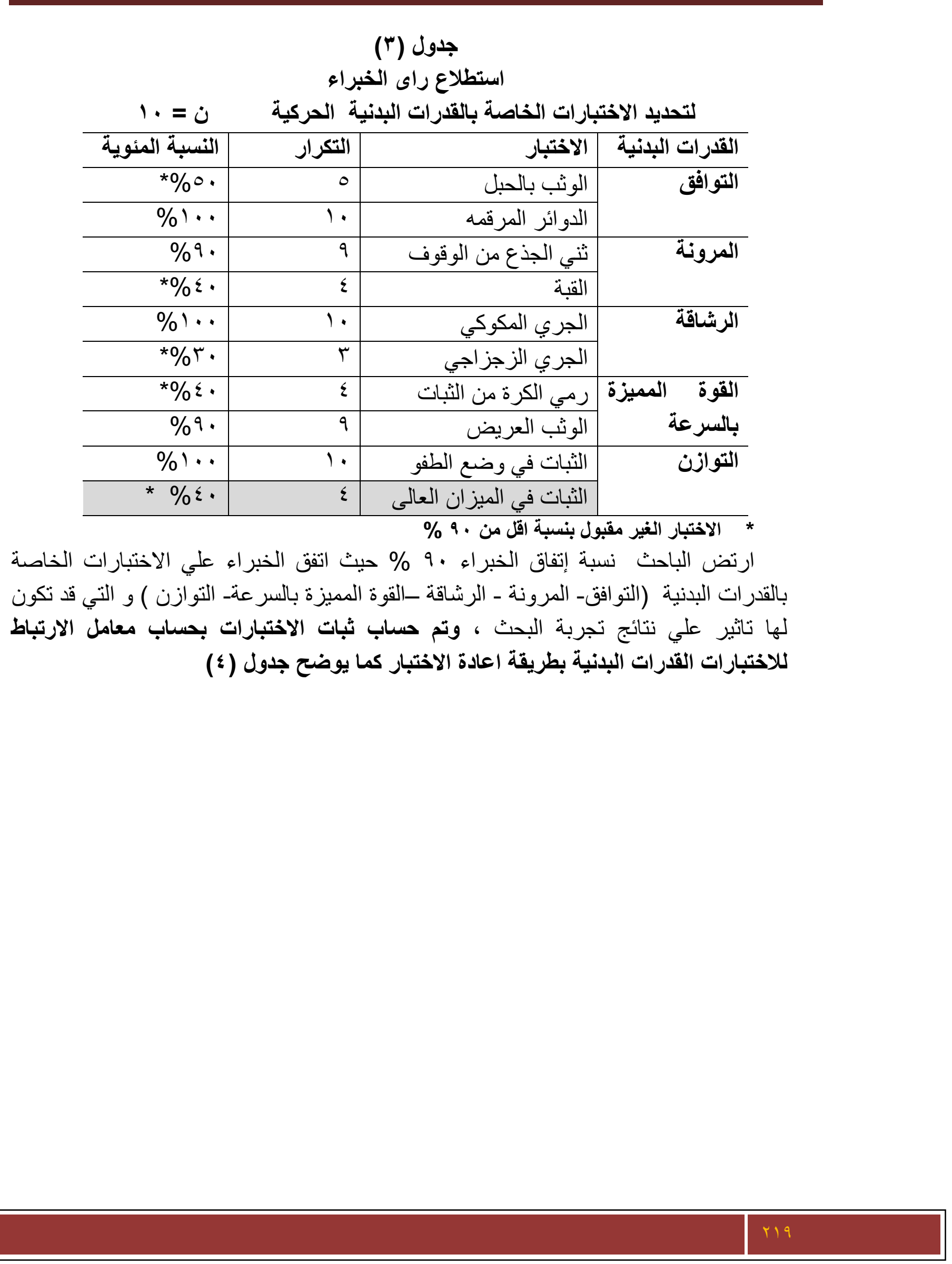




\begin{tabular}{|c|c|c|c|c|c|c|c|}
\hline \multicolumn{8}{|c|}{ 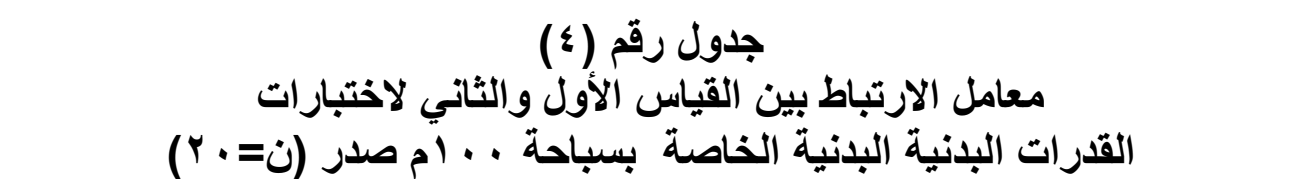 } \\
\hline \multicolumn{3}{|c|}{ معامل } & $ت$ & ثاني تطبيق & تطبيق & \multirow[t]{2}{*}{ الاختبار } & \multirow{2}{*}{ البدرنية } \\
\hline & & $\varepsilon \pm$ & س س & $\varepsilon \pm$ & س س & & \\
\hline$\left.{ }^{*}\right) .$. & $\because \cdots$ & $1 . Y \varepsilon$ & $\varepsilon .9$. & $1 . Y \varepsilon$ & \&.9. & الدو ائر المرقمه & التو افق \\
\hline$\left.{ }^{*}\right) .$. & $\because \cdots$ & $\cdot .71$ & r.01 & $\cdot .71$ & $r .0 \Lambda$ & الوقي الجذع من & المرونة \\
\hline${ }^{*}{ }_{1} . .$. & $\because \cdots$ & $\cdot . \wedge \wedge$ & $7 . \leqslant 0$ & $\cdot . \wedge \wedge$ & 7.50 & الجكري & الرشاقة \\
\hline$\left.{ }^{*}\right) .$. & $\because \cdots$ & $0 . \leqslant 1$ & $111 . \wedge$. & $.0 Y$ & $1 . v$. & العريضب & المبرة \\
\hline$\left.{ }^{*}\right) .$. & $\because \cdots$ & T.VY & $1 T . \leqslant 0$ & $T . V Y$ & $1 T . \leqslant 0$ & وضنع الطفو في & التوازن \\
\hline
\end{tabular}

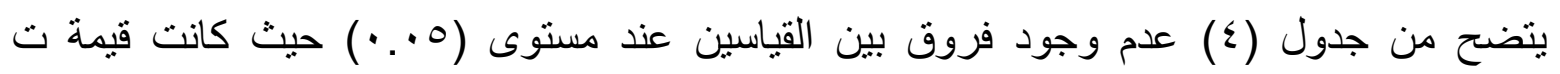

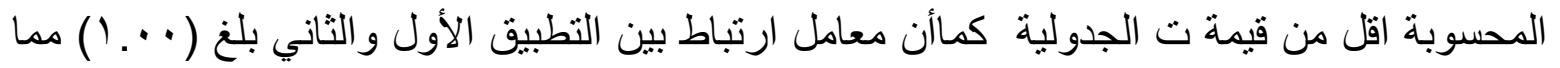
يشير إلى ثبات هذه الاختبار ات. وتم حساب صدق الاختبارات بحساب المقارنة الطرفية بين الاربات الإبى الاعلى والارباعى الادنى الإنى

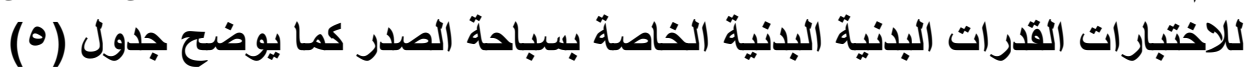


جدول رقم (0) (0)

المقارنة الطرفية بين الارباعى الاعلى والارباعى الادنى

\begin{tabular}{|c|c|c|c|c|c|c|c|c|}
\hline \multirow[t]{2}{*}{ الصدق معامل } & \multirow[t]{2}{*}{ قيمة } & \multirow[t]{2}{*}{ المتوسطين بين } & \multicolumn{2}{|c|}{ الارباعى الادنى } & \multicolumn{2}{|c|}{ 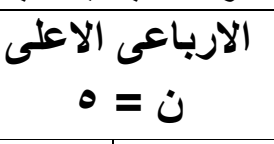 } & \multirow[t]{2}{*}{ الاختبار } & \multirow{2}{*}{ البلانية } \\
\hline & & & $\varepsilon \pm$ & س - س & $\varepsilon \pm$ & س & & \\
\hline$\cdot . \wedge T$ & 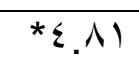 & Y.V. & $\because \cdot$ & $\varepsilon \ldots$ & $1 . r_{0}$ & $7.8 \cdot$ & الدو ائر المرقمه & التو افق \\
\hline$\cdot .9 \varepsilon$ & $* V$ * $\leqslant 1$ & 1. $\varepsilon$. & $\because \cdot$ & r... & $\cdot \varepsilon r$ & 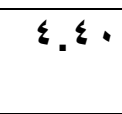 & ثني الجذع من & المرونة \\
\hline .90 & ${ }^{*} \lambda .0 Y$ & $1 . \cdot V$ & $\cdot Y V$ & $0.0 Y$ & $\cdot Y \varepsilon$ & 7.09 & الجري المكوكي & الرشاقة \\
\hline $.9 V$ & $* 1 \cdot .71$ & $1 . r$. & $\because \cdots$ & 1.0. & $\cdot . Y V$ & Y.A. & الوثب العريض & بالسوة الميزة \\
\hline$\cdot \Delta T$ & ${ }^{*} Y . \varepsilon \varepsilon$ & T.TY &. Or & 17.51 & $\{.17$ & $r \cdot . \cdot r$ & الظفبات في وضع & التوازن \\
\hline
\end{tabular}

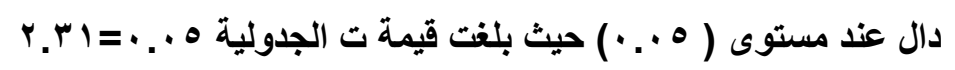

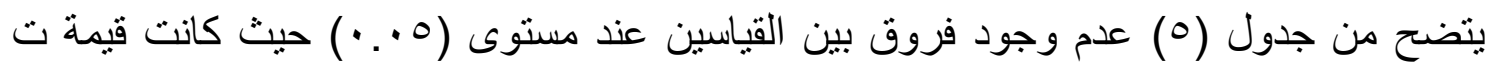

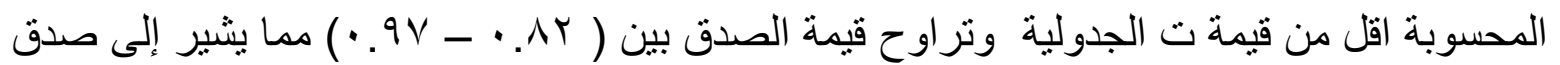
هذه الاختبار ات.

الأجهزة المستخدمة في البحث: جهاز رستاميتر لقياس الطول ـ ميزان طبي لقياس الوزن- ساعة

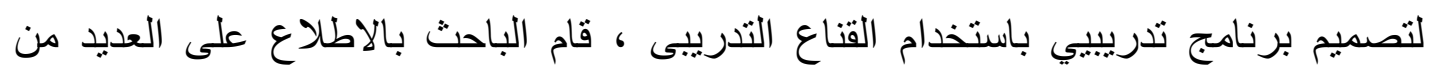

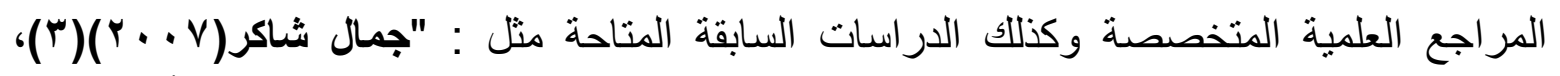

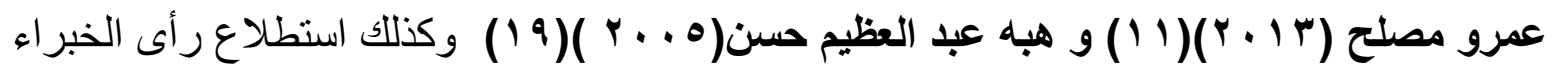

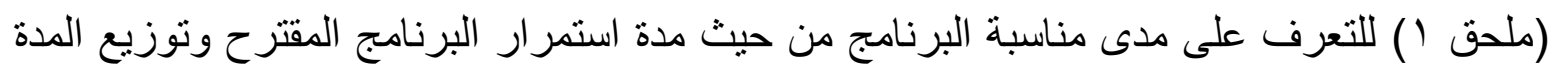

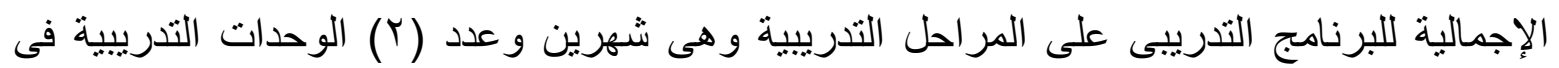

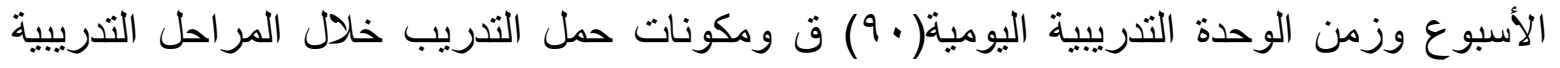

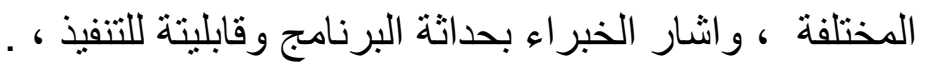

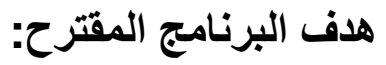

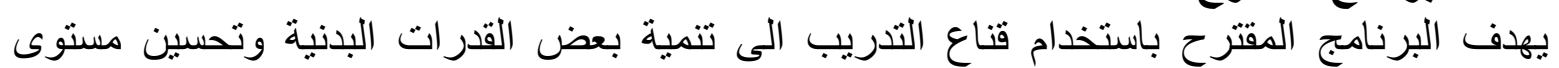

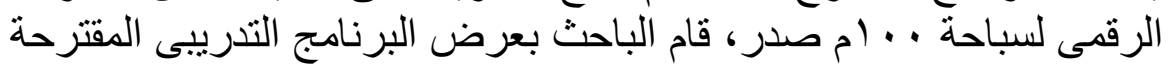


اسس وضع البرنامج المقترح :

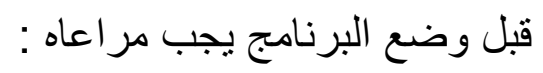

ا - ملائمة المحتوى للمرحلة السنية

r ا ب- مرعاة الفروق الفردية

r- بـ مر عاه الدقة فى اداء التمرينات التردية

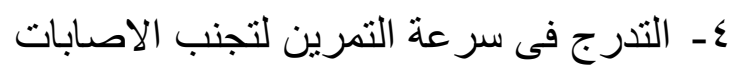

0- وجود عنصر التشويق فى محتوى البرنامج

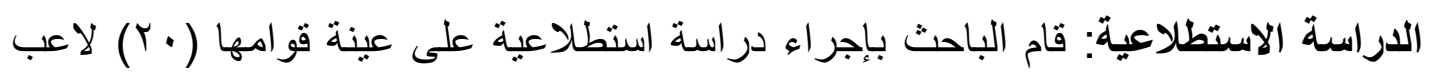

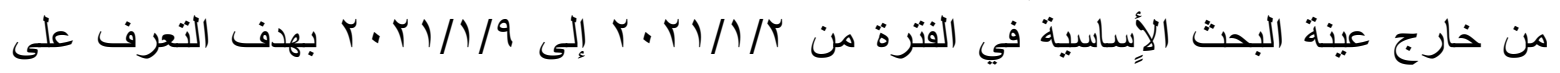

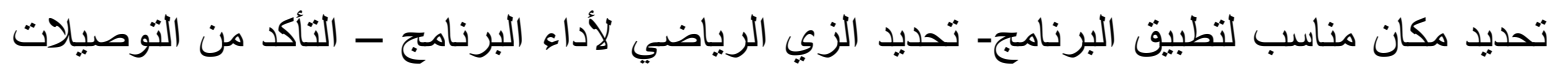

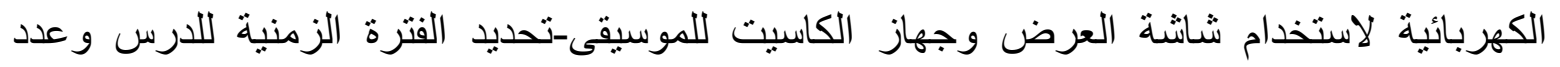
التمرين أسبو عياً - وتم تحديد فترة • 9 دقيقة لتنفيذ الوحد التدريبية على مدار ( • () أسابيع.

\section{التجرية الأساسية تم تنفيذ التجربة الأساسية على ثلاث خطوات التوات}

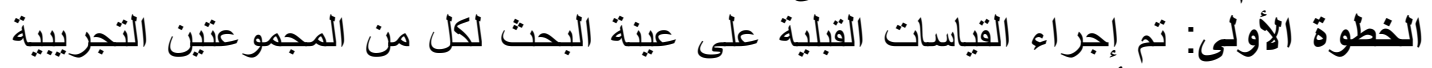

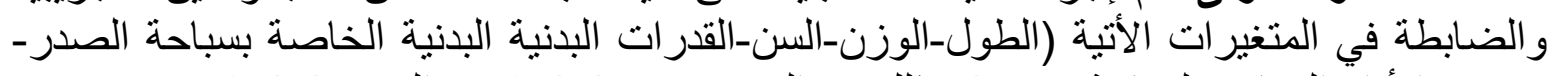

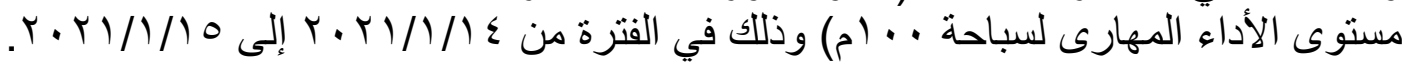

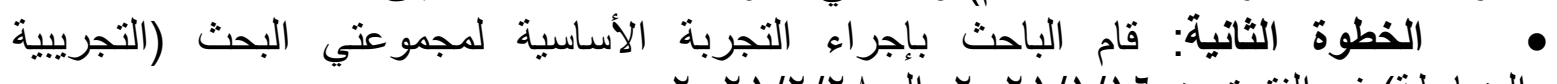

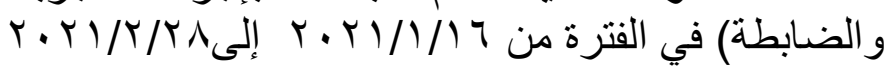

الخطوة الثالثة وتثنتمل على القياسات البعدية

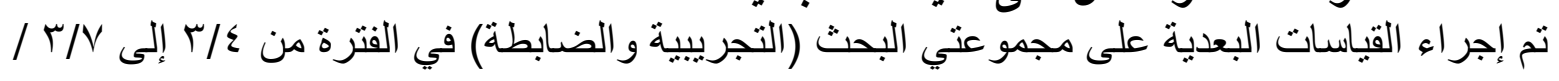

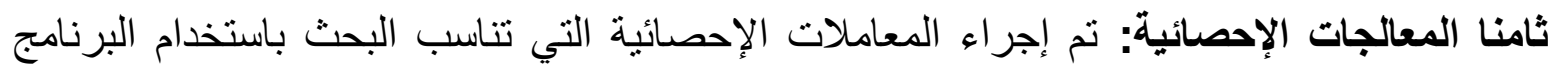

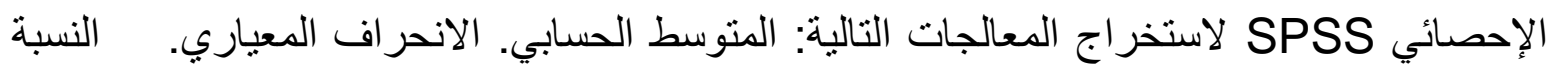

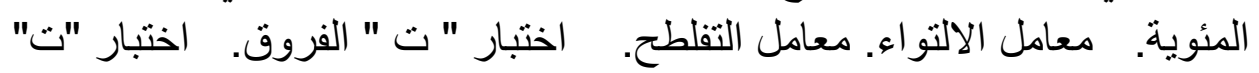
عرض ومناقثة نتائج البحث: سيقوم الباحث بعرض ومناقثة نتائج البحث في ضوء الفروض أولاً: فيما يتعلق بصحة الفرض الأول

ونصد" توجد فروض دالة إحصائيا بين منوسطات القياسين البعديين للمتغيرات البدنية قيد البحث

للمجموعة التجريبية و المجموعة الضابطة ولصالح المجموعة التجريبية ". 


\section{جلول (T)}

دلالة الفروق بين القياس البعدي للمجموعتين الضابطة والتجريبية

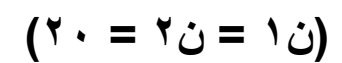

\begin{tabular}{|c|c|c|c|c|c|c|c|c|}
\hline \multirow{2}{*}{ الفربة } & \multirow{2}{*}{ قالمحسوبة "ت" } & \multirow{2}{*}{ المتوسطين بين } & \multicolumn{2}{|c|}{ التجريبية } & \multicolumn{2}{|c|}{ الضابطوة المجة } & \multirow[t]{2}{*}{ الاختبار } & \multirow[t]{2}{*}{ البلنية } \\
\hline & & & $\varepsilon \pm$ & س- & $\varepsilon \pm$ & س- & & \\
\hline$r \cdot$ & r.71- & $.70=$ & 1.99 & 5.90 & .91 & r.7. & الاو ائر المرقمه & التو افق \\
\hline$\leq 9.1$ & $\{.01$ & $r_{.} .0$ & Y.10 & $7.1 \mathrm{~V}$ & $1 . \wedge \varepsilon$ & $\varepsilon .1 r$ & الثني الجذع من & المرونة \\
\hline$r 7.9$ & $\varepsilon . \wedge 7$ & $1 . r=$ & $\therefore .10$ & $\varepsilon . Y$. & $1 \% . r$ & $0 . Y Y$ & الجري المكوكي & الرشاقة \\
\hline rq.r & 7.04 &. .11 & \& & T.Tr & 1.70 & Y. $\leqslant 0$ & الوثب العريض & المالسرة \\
\hline YV.V & $\varepsilon . \mu v$ & 1.41 & 1.11 & 11.79 & r.rq & $1 \cdot .50$ & الطفّت في وضع & التو ازن \\
\hline
\end{tabular}

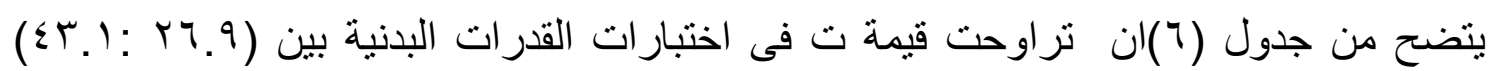

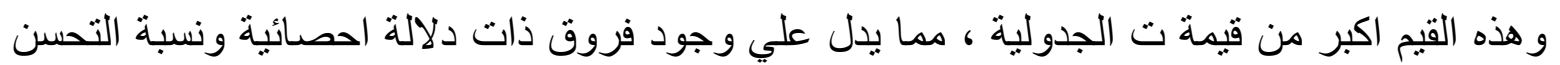

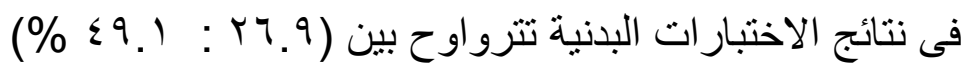

ويعزو الباحث ذلك التفوق إلى إن استخدام وتطبيق وتكرار التدريبات بأستخدام القانع التدريبي والتي ركزت على تطوير القدرات البدنية البدنية منل التوافق والمرونة والرشاقة والقوة المميزة بالسرعة والتوازن والأداء المركب لحركات أجزاء الجسم المختلفة في وقت واحد قد ساعد لاعبين المجموعة

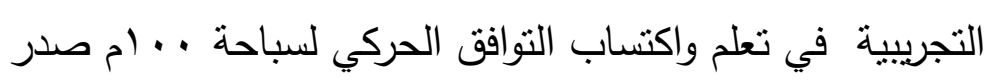

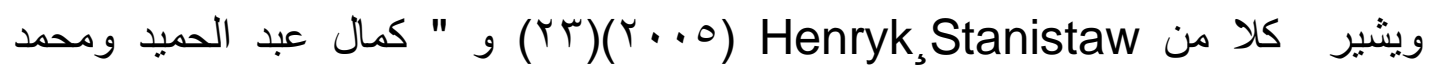

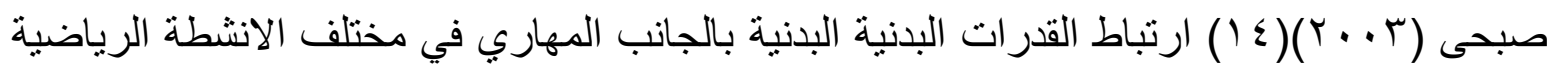

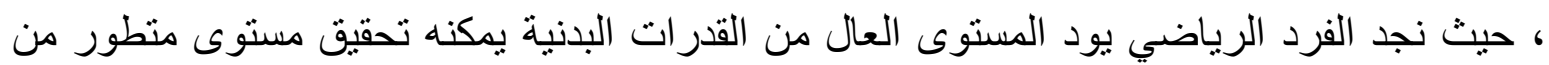

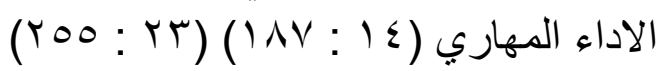

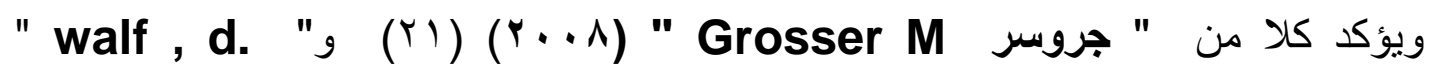

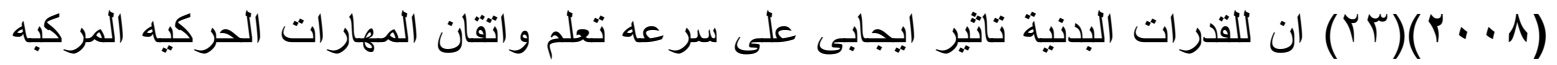

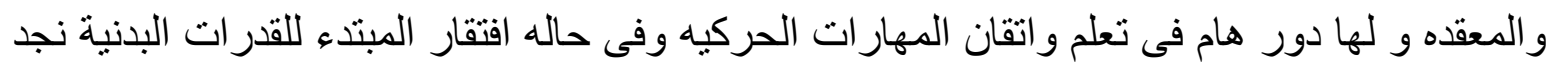

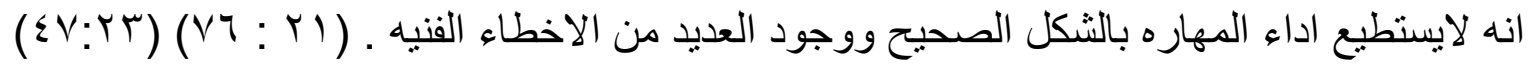




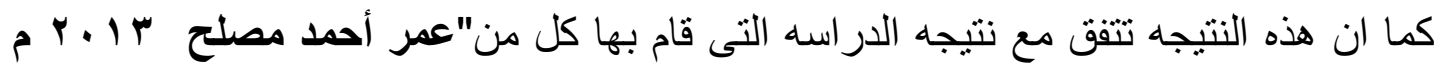

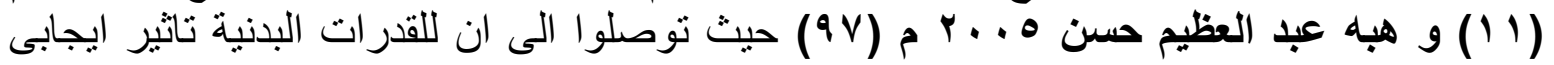
على تعليم وتطوير المستوى المهارى

عرض ومناقشة الفرض الثانى والذى ينص على " توجد فروض دالة إحصائيا بين متوسطات القياسين البعديين للمستوى الرقمي للمجموعة التجريبية و المجموعة الضابطة ولصالح المجموعة

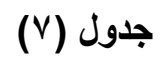

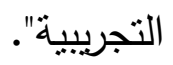

دلالة الفروق بين القياس البعدي اللمجموعتين الضابطة والتجريبية في مستوى اداء سباحة ـ. ـ ام صدر (ن) (r. $=r$ ن $=$

\begin{tabular}{|c|c|c|c|c|c|c|c|}
\hline \multirow{2}{*}{ نسبة } & \multirow{2}{*}{ "قيمة } & \multirow{2}{*}{ المتوسطين } & \multicolumn{2}{|c|}{ التجريبية } & \multicolumn{2}{|c|}{ الضجابطوعة } & \multirow[t]{2}{*}{ الاختبار } \\
\hline & & & $\varepsilon \pm$ & س- س & $\varepsilon \pm$ & س- & \\
\hline 10.0 & $r . \xi V$ & 11.20 & $r . \leqslant 0$ & $7 \leqslant .7$. & $\$ .10$ & $V 7.00$ & زمن للأداء \\
\hline
\end{tabular}

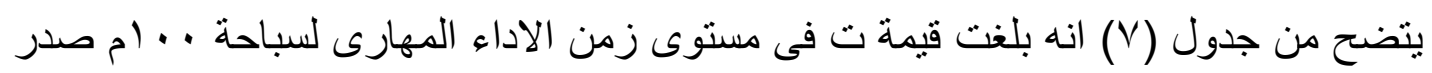

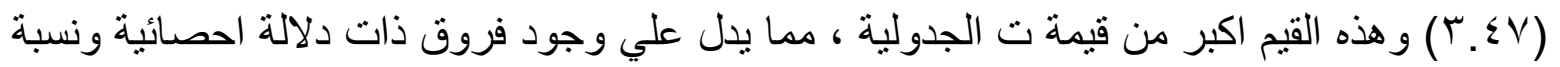

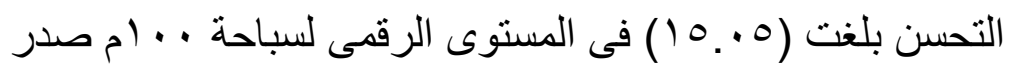

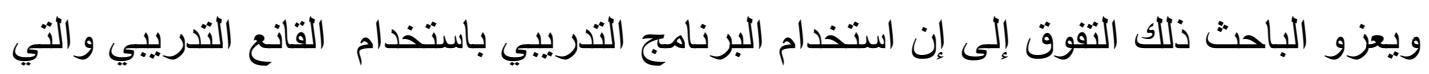

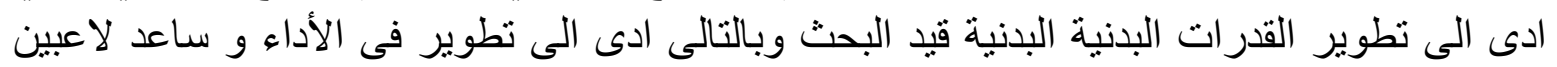

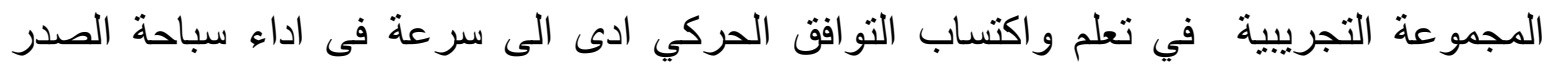

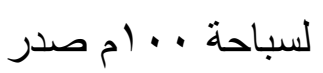

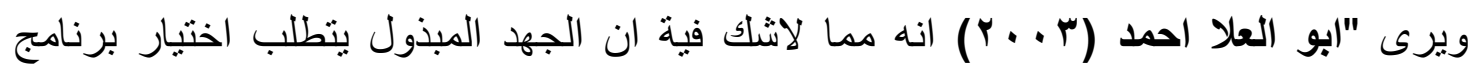

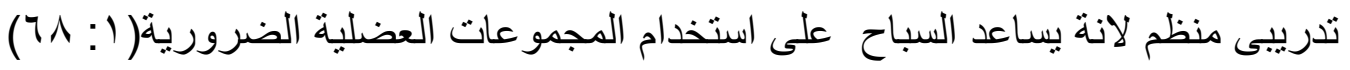

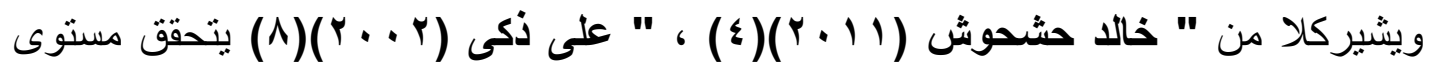

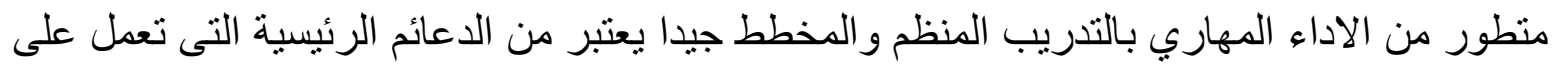

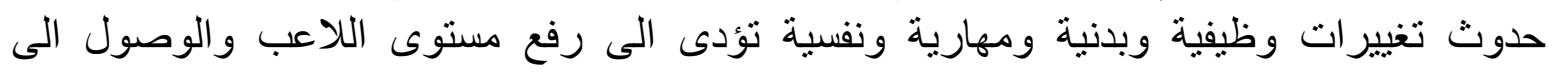


المستويات الرياضية العالية ـ و التدريب بنقص الاكسجين أحد طرق التدريب الحديثة لرفع مستوى الاداء وتدريبات الهييو كسيك هى اداء لتدريبات اثناء تعرض الانسجة لنقص الإكس الاكسجين من خلال

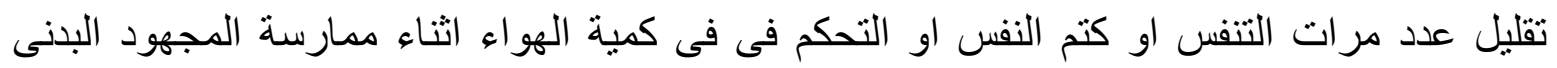

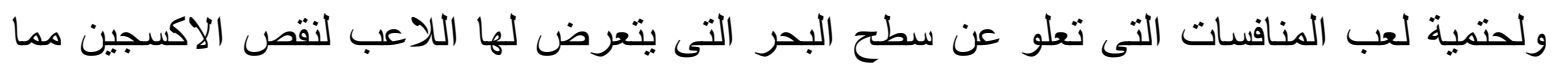

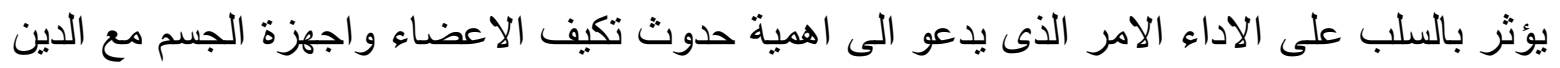

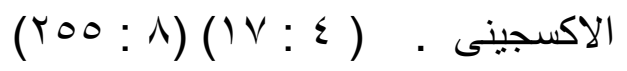

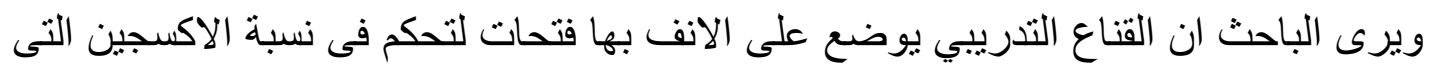

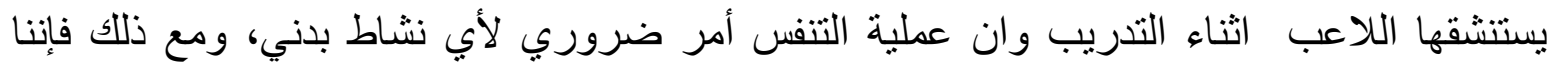

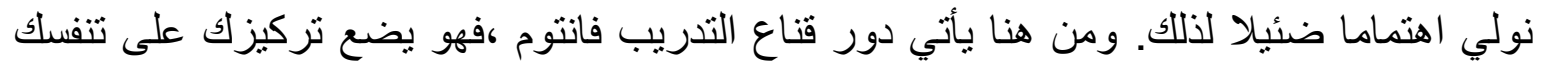

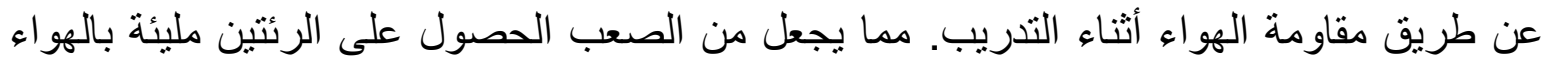
ويقوي عضلات التنفس مما يزيد من أداء اللاعب عند التباء التدريب أو التنافس دون قناع.

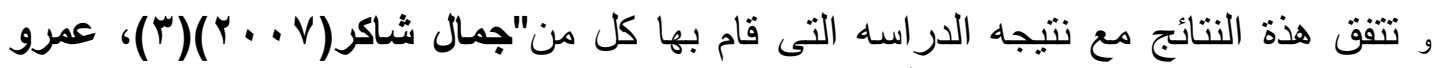

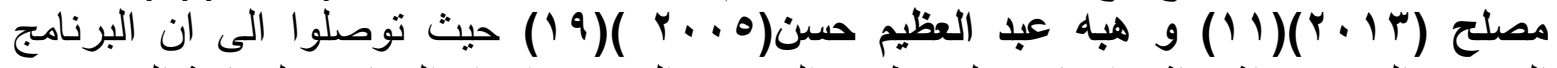

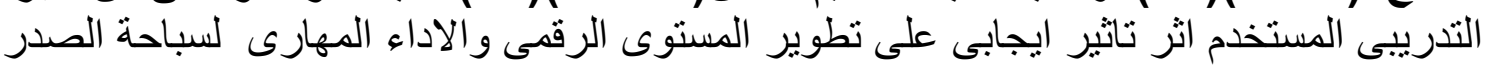

\section{الاستنتاجات : في ضوء نتائج البحث تم التوصل الى الاتي :}

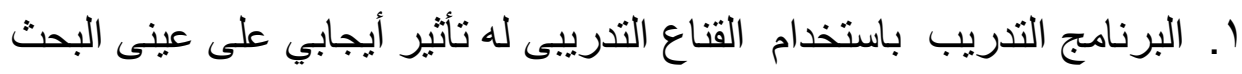

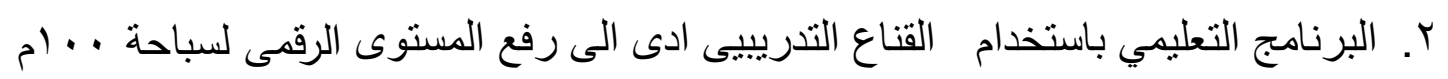

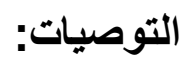

في ضوء ما اسفرت عنه النتائج فإنه يمكن الوصول الي بعض التوصيات الاتية:" القدرات البدنية البدنية مهمة لتعليم مهار ات السباحة ويجب علي الددربين الاهتمام بها إجر اء المزيد من هذه الدراسات على سباحات أخرى. 


\section{المراجع}

\section{اولا : المراجع العربية}

ا- ابو العلا احمد عبد الفتاح r...r: فسيولوجيا التدريب والرياضة ، دار الفكر العربي،

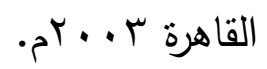

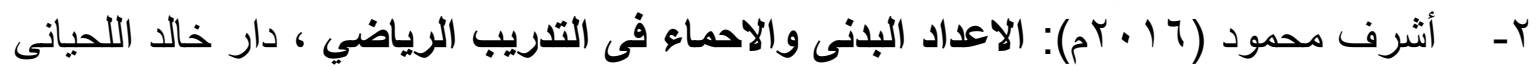

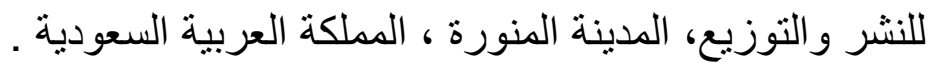

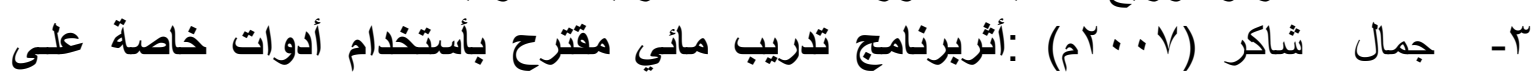

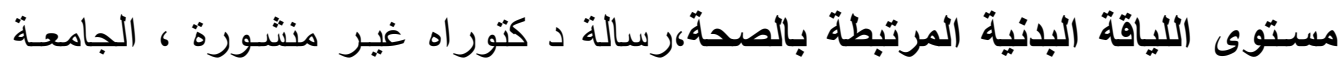

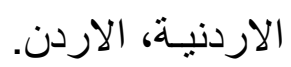

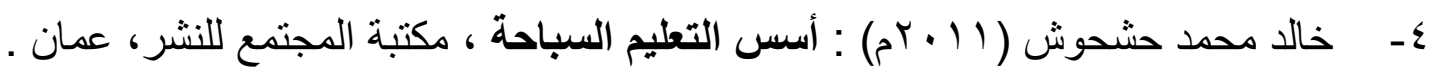

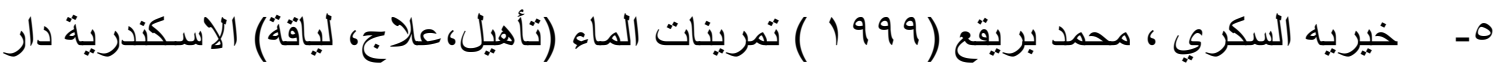

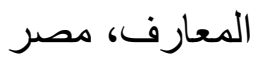

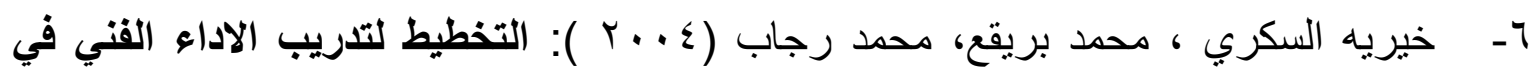

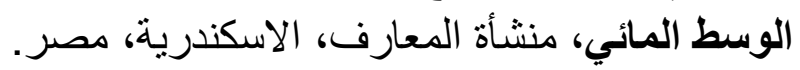

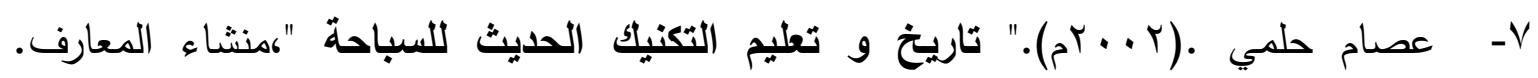

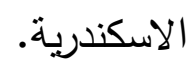

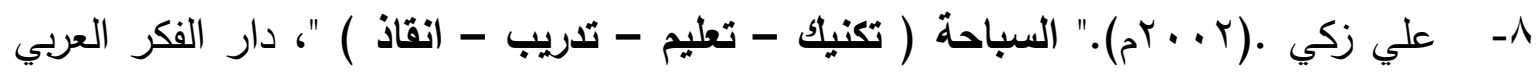
القاهزة

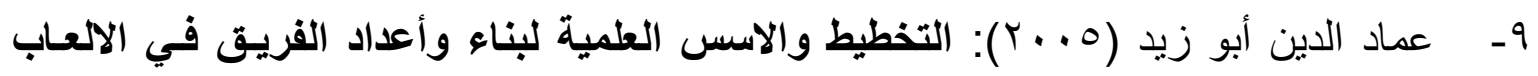

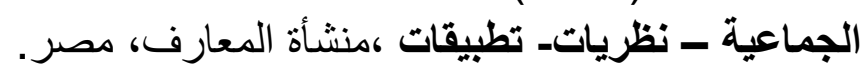

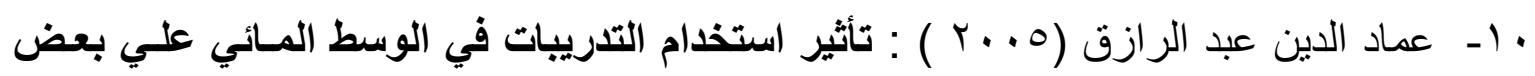

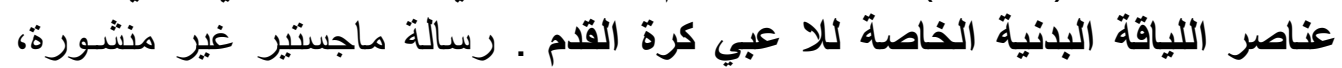

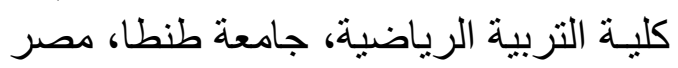

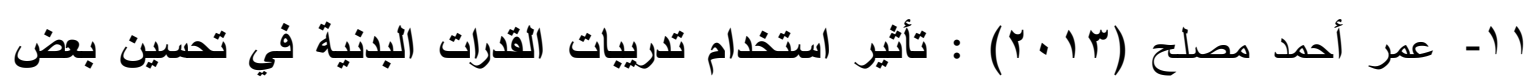

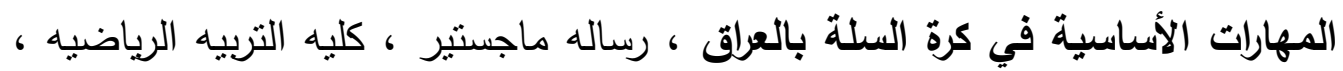

$$
\text { جامعه الاسكندريه . }
$$

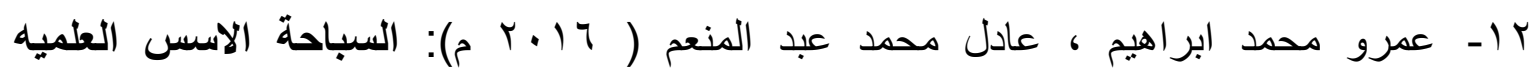
والتطبيقية ،مركز الكتاب للنشر ،القاهرة . 


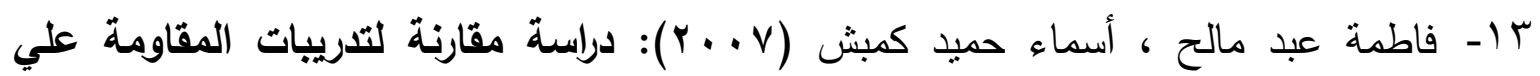
اليابسة وفي الوسط المائي علي تظوير بعض القدرات الخاصة بالوثبة الثثلاثية ، مجلة

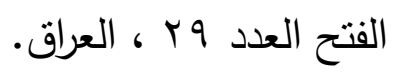

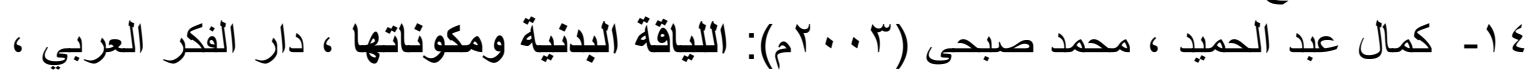

$$
\text { طس ، القاهرة . }
$$

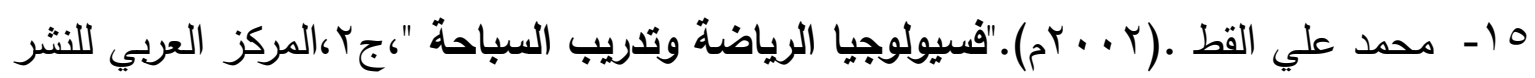
.القاهرة .

7 ا - محمد علي القط .(0 . ㄷم)." استراتيجية التريب الرياضي في السباحة" ، المركز العربي

$$
\text { • للنشر ، القاهرة }
$$

V I - محد فتحي الكرداني ، يحيي مصطفي علي (ع ا • rم): السباحة (تعليم - تدريس - برامج)،

$$
\text { دار الوفاء ،الاسكندرية . }
$$

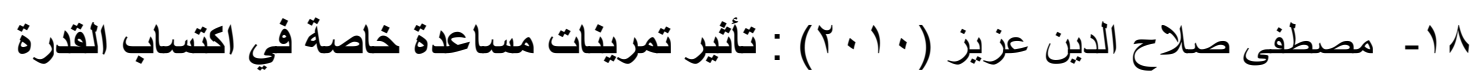

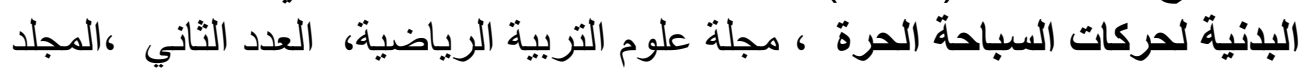

$$
\text { الثالث. }
$$

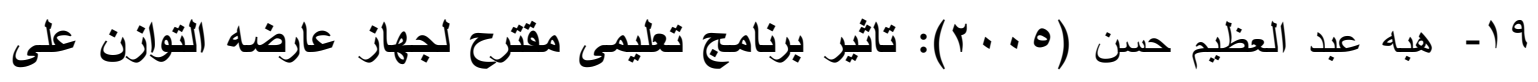
القرات البانية ومستوى الاداء المهارى للاعبين كليه التربيه الرياضيه ، رساله دكتوراه

$$
\text { ، كليه التربيه الرياضيه جامعه اسيوط . }
$$

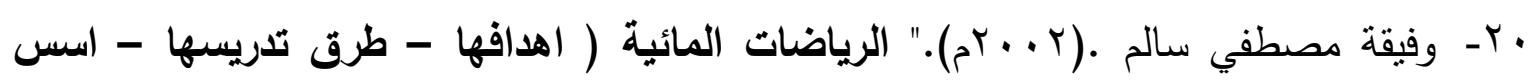

$$
\text { تدريبها - اساليب تقويمها )"، منشأة المعارف الاسكندرية. }
$$

ثانياً : المراجع الاجنبية

21-Grosser M. , Starischka S. , Zimmermann E.(2008) : Das e konditionstraining. BLV Buchverlag, Munchen .

22- Henryk, Stanistaw (2000):Effects of massage on physiological restoration. Perceived recovery and repeated sports performance $\mathrm{Br}-\mathrm{J}-$ Sports-Med. April: 34 (2) 
23-Walf droge (2008) : free radicalism physiological control of function American physiological society .

ثالثاً : المو اقع الثبكة الدولية للمعلومات

24- $\quad$ http://www.badnia.net/badnia/showthread.php?t=36 


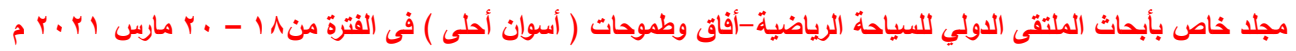

